\title{
Species-Specific Duplex PCR for Detecting the Important Fish Pathogens Vibrio anguillarum and Edwardsiella tarda
}

\author{
Geon-A Jo, Sae-Bom Kwon, Na-Kyeong Kim, Muhammad Tofazzal Hossain, Yu-Ri Kim, Eun-Young Kim \\ and In-Soo Kong*
}

Department of Biotechnology, Pukyong National University, Busan 608-737, Korea

\begin{abstract}
Vibriosis caused by Vibrio anguillarum and edwardsiellosis caused by Edwardsiella tarda are septicemic diseases of many commercially important freshwater and marine fishes, and threaten the aquaculture industry in Korea. Early diagnosis and accurate identification of these two bacterial species could help to prevent these diseases and minimize the damage to cultured marine species. This study designed a duplex polymerase chain reaction (PCR) method for the simultaneous detection of two major fish pathogens: $V$. anguillarum and $E$. tarda. Each pair of oligonucleotide primers exclusively amplified the target groEL gene of the specific microorganism. Twenty-two Vibrio and ten non-Vibrio enteric species were used to check the specificity of the primers, which were found to be highly specific for the target species, even among closely related species. The detection limit was $400 \mathrm{pg}$ for $V$. anguillarum and $4 \mathrm{ng}$ for $E$. tarda when mixed purified DNA was used as the template. This assay showed high specificity and sensitivity in the simultaneous detection of $V$. anguillarum and $E$. tarda from artificially inoculated seawater and fish.
\end{abstract}

Key words: Duplex PCR, detection, E. tarda, groEL gene, V. anguillarum

\section{Introduction}

Vibrio anguillarum, which causes vibriosis, and Edwardsiella tarda, which causes edwardsiellosis, are the two most common agents causing septicemic diseases in many commercial freshwater and marine fishes, including catfish, salmon, eel, turbot, and flounder (Lan et al., 2008; Frans et al., 2011). In recent years, both species have threatened the aquaculture industry in Korea, causing increased losses from infections (Park, 2009). V. anguillarum also affects bivalve mollusks and crustaceans (Paillard et al., 2004; Frans et al., 2011), while E. tarda also causes gastroenteritis and generalized infections, mainly among individuals with impaired immunity (Rao et al., 2001). The early diagnosis and accurate identification of these species could promote disease prevention and minimize damage to cultured freshwater and marine species.

In recent years, DNA-based methods have been developed for the fast, sensitive identification of pathogens of many aquatic species (Toranzo et al., 2005). PCR-based methods targeting the $16 \mathrm{~S}$ rRNA, recA, hemolysin, empA, rpoN, amiB, and $r p o S$ genes have been developed for detecting $V$. anguillarum (Kita-Tsukamoto et al., 1993; Rodkhum et al., 2006; Kim et al., 2008), while PCR-based methods targeting the $16 \mathrm{~S}$ rRNA, gyrB, etfA, etfD, and hemolysin genes have been developed for E. tarda (Lan et al., 2008; Castro et al., 2010). However, most of these methods fail to detect the two species specifically because of high levels of identity, gene mutations, and reduced sensitivity in environmental samples (Castro et al., 2010; Kim et al., 2010). The groEL gene encodes the chaperonin GroEL (synonyms are Cpn 60, GroL, Hsp 60, and Mop A), which plays an essential role in the control of cellular stress and is a powerful phylogenetic marker (Junick
http://dx.doi.org/10.5657/FAS.2013.0273

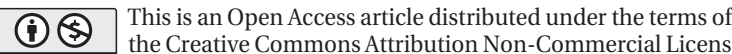
(http://creativecommons.org/licenses/by-nc/3.0/) which permits unrestricted non-commercial use, distribution, and reproduction in any medium, provided the original work is properly cited.
Received 25 April 2013; Revised 02 September 2013

Accepted 16 September 2013

*Corresponding Author

E-mail: iskong@pknu.ac.kr 
and Blaut, 2012). The superiority of the groEL gene compared to $16 \mathrm{~S}$ and $23 \mathrm{~S}$ rRNA has been reported in the detection of Vibrio species (Nishibuchi, 2006; Yushan et al., 2010). This gene is also a proven marker for the species-specific detection of many bacteria, including Vibrio species (Kim et al., 2010, 2012; Yushan et al., 2010; Hossain et al., 2012, 2013). Kim et al. (2010) developed a simplex PCR method targeting this gene and successfully used it to specifically detect $V$.

Table 1. Strains used in the study

\begin{tabular}{|c|c|}
\hline Microorganisms & Source or reference \\
\hline Vibrio aestuarianus & KCCM 40863 \\
\hline V. alginolyticus & КCTC 2472 \\
\hline V. anguillarum & КСТC 2711, J-O-2, J-O-3, YT, NB10 \\
\hline V. campbellii & КССМ 41986 \\
\hline V. cholerae & KCTC 2715 \\
\hline V. cincinnatiensis & КСТC 2733 \\
\hline V. damsella & E \\
\hline V. diazotrophicus & КСCM 41606 \\
\hline V. fluvialis & ATCC 33809 \\
\hline V. furnissii & КCTC 2731 \\
\hline V. harveyi & KCCM 40866 \\
\hline V. logei & КСТC 2721 \\
\hline V. mediterranei & KCCM 40867 \\
\hline V. metschnikovii & KCTC 2736 \\
\hline V. mimicus & ATCC 33653 \\
\hline V. natriegens & KCCM 40868 \\
\hline V. navarrensis & KCCM 41682 \\
\hline V. nereis & KCCM 41667 \\
\hline V. ordalii & KCCM 41669 \\
\hline V. parahaemolyticus & KCCM 11965 \\
\hline V. proteolyticus & КСТC 2730 \\
\hline V. vulnificus & KCCM 41665 \\
\hline Aeromonas hydrophila & KCTC 2358 \\
\hline Edwardsiella tarda & KCTC $12267, \mathrm{E}$ \\
\hline E. ictaluri & KCTC 12264 \\
\hline Enterobacter cloacae & $\mathrm{E}$ \\
\hline Escherichia coli & $\mathrm{L}, \mathrm{E}$ \\
\hline Klebsiella oxytoca & $\mathrm{E}$ \\
\hline K. pneumoniae & $\mathrm{E}$ \\
\hline Salmonella Typhi & E \\
\hline Shigella flexneri & E \\
\hline S. sonnei & E \\
\hline
\end{tabular}

KCCM, Korean Culture Center of Microorganisms, Korea; KCTC, Korean Collection for Type Cultures, Korea; E, environmental strain; ATCC, American Type Culture Collection, USA; L, laboratory collection. anguillarum. To date, there is no report of the simultaneous detection of both species in a large group of infected fish by PCR. Therefore, we developed a duplex PCR method using the groEL gene for the simultaneous, species-specific detection of $V$. anguillarum and E. tarda.

\section{Materials and Methods}

\section{Bacterial strains and growth medium}

Twenty-six Vibrio strains and 12 non-Vibrio strains, including the target species (five for $V$. anguillarum and two for E. tarda), reference strains representing 21 other Vibrio species, and nine other non-Vibrio enteric species were examined (Table 1). All of the bacterial species except Escherichia coli, E. tarda, and Edwardsiella ictaluri were grown aerobically in brain heart infusion broth (BD, Franklin Lakes, NJ, USA) supplemented with $0.5-3 \%$ sodium chloride. E. coli was grown in Luria-Bertani broth (USB, Cleveland, OH, USA). E. tarda and E. ictaluri were cultured in nutrient agar (USB).

\section{Primer design}

All available groEL sequences for Vibrio and non-Vibrio enteric species were retrieved from GenBank using the search software blastn provided by the National Center for Biotechnology Information. The nucleotide sequences were compared using ClustalW to design the species-specific oligonucleotide primer sets Va-groD1 and Va-groD2 (for V. anguillarum) and Et-groD1 and Et-groD2 (for E. tarda), yielding specific amplicons of 379 and $623 \mathrm{bp}$, respectively (Table 2).

\section{Duplex PCR assay}

Genomic DNA for all of the Vibrio and non-Vibrio strains was purified using the methods of Ausubel et al. (1998) and identified using a primer set designed to target $16 \mathrm{~S}$ rRNA. Duplex PCR was carried out in a reaction mix containing $1 \mu \mathrm{L}$ of purified genomic DNA, $5 \mu \mathrm{L}$ of $10 \times$ PCR buffer containing $\mathrm{MgCl}_{2}, 4 \mu \mathrm{L}$ of dNTPs (2.5 mM each), $0.25 \mu \mathrm{L}$ of Ex Taq Polymerase (Takara Bio, Shiga, Japan), primers (Va-groD1, Va-groD2, Et-groD1, and Et-groD2; 1.0 pmol each), and ster-

Table 2. Oligonucleotide primers used in this study

\begin{tabular}{|c|c|c|c|c|}
\hline Target gene & Primer & Oligonucleotide sequence & Amplicon size (bp) & Reference \\
\hline \multirow[t]{2}{*}{ 16S rRNA } & $16 \mathrm{~S} 1$ & 5'-AGAGTTTGATCMTGGCTCAG-3' & 1,466 & Kim et al. (2008) \\
\hline & $16 \mathrm{~S} 2$ & 5'-TACGGYTACCTTGTTACGACTT-3' & & \\
\hline \multirow[t]{2}{*}{ groEL of Vibrio anguillarum } & Va-groD1 & 5'-AGGTGAAGAGCAAGCCATTAAAGTT-3' & 379 & Present study \\
\hline & Va-groD2 & 5'-ATCCTCTTCGCCCGCGTTTTTCAC-3' & & \\
\hline groEL of Edwardsiella tarda & Et-groD1 & 5'-TGACTCTAAAGCCATTGCGCAGGTA-3' & 623 & Present study \\
\hline
\end{tabular}




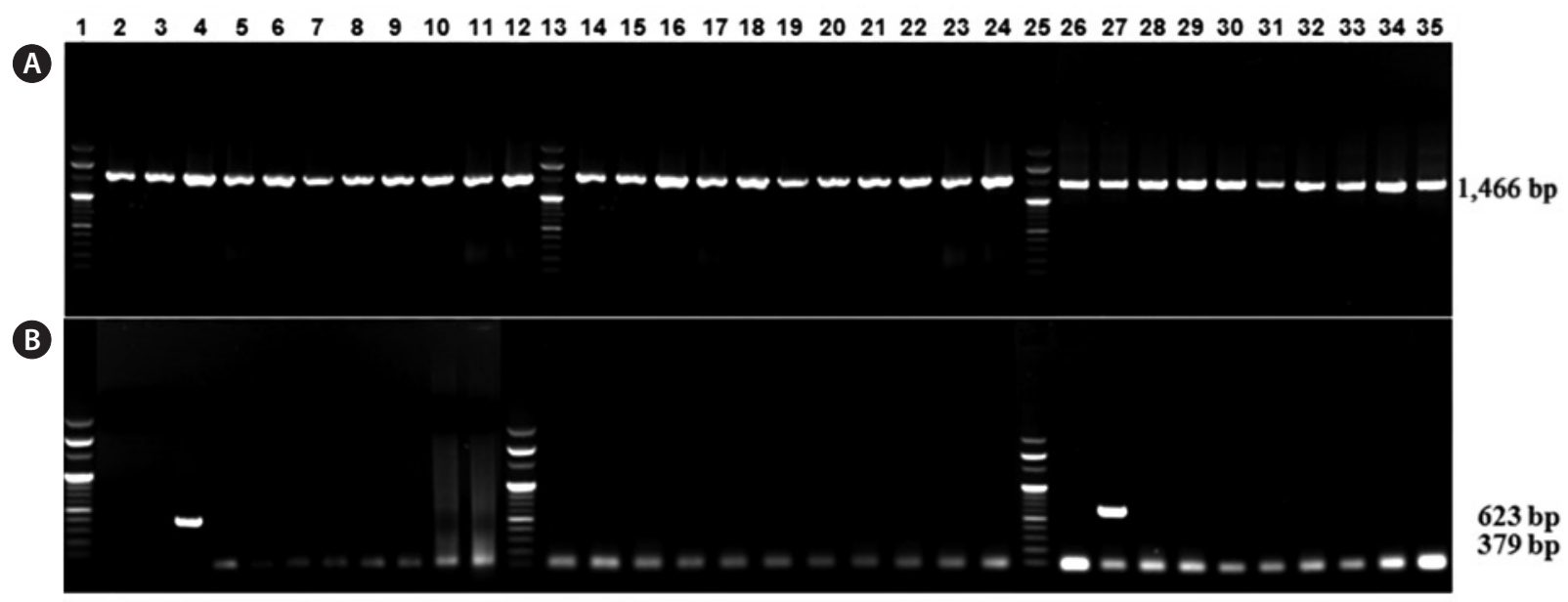

Fig. 1. Results of the PCR analysis of Vibrio and non-Vibrio species using a $16 \mathrm{~S}$ rRNA primer set (A) and duplex PCR using groEL primer sets (B). Lanes 1, 13, and 25, 100-bp DNA ladder; lanes 2-12, 14-24, and 26-35, V. aestuarianus, V. alginolyticus, V. anguillarum (KCTC 2711), V. campbellii, V. cholerae, V. cincinnatiensis, V. damsella, V. diazotrophicus, V. fluvialis, V. furnissii, V. harveyi, V. logei, V. mediterranei, V. metschnikovii, V. mimicus, V. natriegens, V. navarrensis, V. nereis, V. ordalii, V. parahaemolyticus, V. proteolyticus, V. vulnificus, A. hydrophila, E. tarda (KCTC 12267), E. ictaluri, E. cloacae, E. coli, K. oxytoca, K. pneumoniae, S. typhi, S. flexneri and S. sonnei, respectively.

ile distilled water (to a total volume of $50 \mu \mathrm{L}$ ). The PCR thermal cycling program consisted of denaturation at $94^{\circ} \mathrm{C}$ for 5 min, followed by 30 cycles of $94^{\circ} \mathrm{C}$ for $30 \mathrm{~s}, 67^{\circ} \mathrm{C}$ for $30 \mathrm{~s}$, and $72^{\circ} \mathrm{C}$ for $30 \mathrm{~s}$, and a final 5 -min extension at $72^{\circ} \mathrm{C}$. The PCR products were analyzed by $1 \%$ agarose gel electrophoresis. The specificity and sensitivity of the duplex PCR assay were determined using the method of Hossain et al. (2012). Briefly, the specificity of the primers designed to detect $V$. anguillarum and E. tarda was determined using 24 Vibrio and 8 nonVibrio enteric species by duplex PCR. The sensitivity with groEL primers was evaluated using pure genomic DNA of $V$. anguillarum and E. tarda. A 4- $\mu$ g aliquot of purified DNA of both species was serially diluted 10 -fold ( $4 \mu \mathrm{g}$ to $0.4 \mathrm{pg}$ ) in distilled water and used as templates for duplex PCR.

\section{Detection of $V$. anguillarum and $E$. tarda in inocu- lated flounders and seawater}

Four groups of 16 apparently healthy flounder Paralichthys olivaceus were maintained separately in $15-\mathrm{L}$ tanks at $20^{\circ} \mathrm{C}$ for 2 weeks. The fish in the three groups were injected intraperitoneally with $V$. anguillarum $\left(2.1 \times 10^{8} \mathrm{CFU} / \mathrm{mL}\right), E$. tarda $\left(2.7 \times 10^{7} \mathrm{CFU} / \mathrm{mL}\right)$, or both species; the fish in the other group were used as uninoculated controls. The internal organs (intestine, liver, spleen and kidney) from inoculated and uninoculated fish were removed aseptically $48 \mathrm{~h}$ post-infection to check the efficacy of newly developed duplex PCR in the rapid detection of target species. Total DNA was extracted from the fish tissues using a DNA extraction kit (NucleoGen Biotech, Siheung, Korea). To examine whether $V$. anguillarum and E. tarda could be detected in seawater by duplex PCR with groEL primers, sterilized seawater $(\sim 300 \mathrm{~mL})$ was artifi- cially inoculated with $V$. anguillarum, E. tarda, or a mixture of the two species used to infect flounder, and incubated at $37^{\circ} \mathrm{C}$ for $24 \mathrm{~h}$. Bacterial chromosomal DNA was extracted from inoculated seawater using the method of Hossain et al. (2012). Briefly, inoculated seawater was collected and filtered using 0.2- $\mu \mathrm{m}$ membrane filters (Advantec, Tokyo, Japan). The filter paper was placed in a plastic conical tube and $5 \mathrm{~mL}$ of distilled water were added. The contents of the filter paper were removed in distilled water by vortexing and centrifuged. Then, the pellet was resuspended and boiled at $100^{\circ} \mathrm{C}$ for $15 \mathrm{~min}$. The supernatant was collected as a source of template DNA and stored at $-20^{\circ} \mathrm{C}$.

The detection of both species from artificially inoculated seawater and infected flounder organs was performed by duplex PCR using the extracted DNA as a template and groEL primers.

\section{Results}

\section{Uniplex and duplex PCR}

A 1,466-bp band was obtained from all tested Vibrio and non-Vibrio species after PCR using 16S rRNA primers (Fig. 1A). The Va-groD1 and Va-groD2 primers amplified a 379-bp band for $V$. anguillarum, while the Et-groD1 and Et-groD2 primers amplified a 623-bp band for E. tarda reference strains with both simplex and duplex PCR (Fig. 2).

\section{Primer specificity}

A specific amplicon was also produced for all test strains of 


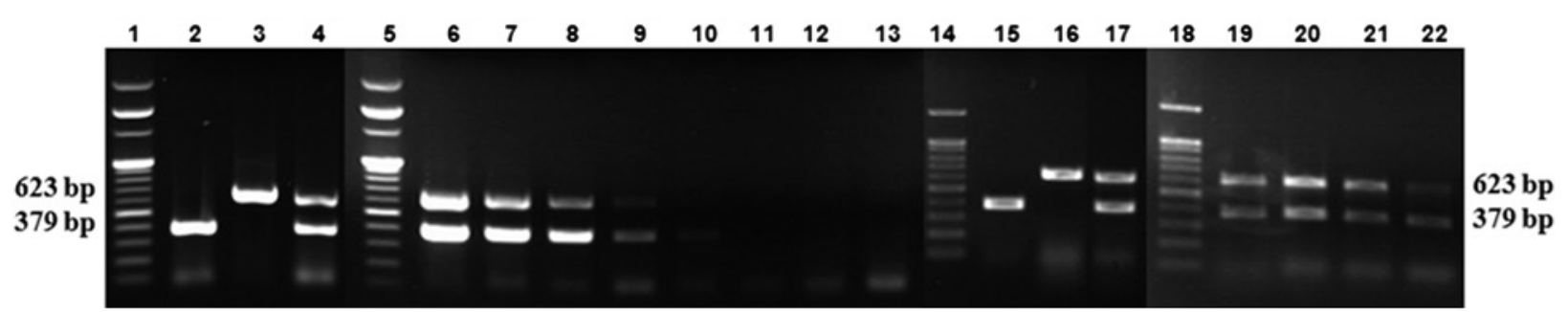

Fig. 2. Agarose gel electrophoresis (1\%) of DNA products amplified during the standardisation of duplex PCR (lanes 2-4), sensitivity of duplex PCR for the simultaneous detection of $V$. anguillarum and $E$. tarda (lanes 6-13) and detection of $V$. anguillarum ( $379 \mathrm{bp}$ ) and $E$. tarda (623 bp) in artificially inoculated seawater (lanes 15-17) and infected flounder organs (lanes 19-22). Lanes 1, 5, 14, and 18, 100-bp DNA ladder; lane 2, V. anguillarum (379 bp); lane 3, E. tarda (623 bp); lane 4, both species; lanes 6-13, 10-fold serial dilution of purified chromosomal DNA (4 $\mu \mathrm{g}$ to $0.4 \mathrm{pg}$ ) from both species; lane 15, seawater inoculated with $V$. anguillarum; lane 16, seawater inoculated with $E$. tarda; lane 17, seawater inoculated with a mixture of both species; lanes 19-22, organs (intestine, kidney, liver, and spleen, respectively) from flounder that had been artificially infected with both bacterial species.

$V$. anguillarum and E. tarda (data not shown). No amplicon of a specific size was observed for non-target Vibrio species or other non-Vibrio enteric species when the primer sets were checked for specificity in the detection of $V$. anguillarum and E. tarda by duplex PCR. Non-specific amplicons of different sizes were not produced in any case (Fig. 1B). Our PCR assay showed good efficacy with a mixed population of target species in the same sample, and the species-specific primer sets produced amplicons that were easily distinguishable by electrophoresis.

\section{Sensitivity of PCR detection}

The groEL primers could detect $400 \mathrm{pg}$ for $V$. anguillarum and $4 \mathrm{ng}$ for $E$. tarda when purified DNA of each species was diluted (data not shown), but detection was possible up to 4 ng from the dilution of mixed purified DNA of both species (Fig. 2).

\section{Detection of $V$. anguillarum and $E$. tarda in inocu- lated flounders and seawater}

The groEL primer set specifically and accurately detected $V$. anguillarum and E. tarda in all organs obtained from individually injected flounders (data not shown) and seawater samples (Fig. 2) using duplex PCR. For samples inoculated with both species, specific products for $V$. anguillarum and E. tarda were amplified when DNA extracted from all organs of the injected flounders was used as the template for duplex PCR (Fig. 2). Both species were also detected in all of the seawater samples using duplex PCR (Fig. 2).

\section{Discussion}

Molecular methods are effective for diagnosing bacterial agents because they permit specific, sensitive detection (González et al., 2004). The simplicity and rapidity of PCR are its greatest advantages over other DNA-based detection methods and immunoassays. The absence of toxin genes in non-virulent strains has prevented these toxin genes from being useful targets for species-specific identification of bacterial pathogens (Chizhikov et al., 2001). Therefore, designing a PCR method based on a phylogenetic marker would be valuable (Izumiya et al., 2011). In the last few years, new PCR methods that target housekeeping genes such as pho, amiB, dnaJ, gyrB, rроA, and rроB have been developed (Jeyasekaran et al., 2011). Although the groEL gene is very highly conserved, this gene in bacteria is more heterogeneous than the $16 \mathrm{~S}$ and 23S rRNA genes (Nishibuchi, 2006; Yushan et al., 2010). The groEL gene is reportedly applicable to interspecies differentiation as a target gene. Recently, we developed PCR for V. anguillarum, V. cholerae, V. parahaemolyticus, and V. vulnificus (Kim et al., 2010; Hossain et al., 2012, 2013) and DNA array detection methods (Kim et al., 2012) using the groEL gene, and found high specificity for detecting particular species.

Our duplex PCR successfully detected $V$. anguillarum and E. tarda without false-positive results from non-target species. The species-specific primer sets also produced amplicons of different sizes that were easily distinguishable by electrophoresis. The detection levels of both uniplex and duplex PCR assays from mixed, purified genomic DNA of the two target species were similar. A similar detection limit was observed in our previous study that used groEL gene primers to detect $V$. cholerae, $V$. parahaemolyticus, $V$. vulnificus, and $V$. anguillarum (Kim et al., 2010; Hossain et al., 2012). During a disease outbreak or when screening samples, the first goal is to detect a particular pathogen at the species level, instead of the strain level. Our duplex PCR method is suitable in this context and the pathogenic strains can be confirmed using virulence markers if necessary.

In conclusion, the duplex PCR assay developed in this study is a highly sensitive and specific assay for the simultaneous detection of $V$. anguillarum and E. tarda. This simple, rapid method will help the aquaculture industry to predict the 
risk associated with these two species. To evaluate the efficacy of this duplex PCR method, environmental and clinical samples are required.

\section{Acknowledgements}

This work was supported by the Korea Foundation for the Advancement of Science \& Creativity (KOFAC) grant funded by the Korean Government (MEST).

\section{References}

Ausubel FM, Brent R, Kingston RE, Moore DD, Seidman JG, Smith JA and Struhl K. 1998. Current Protocols in Molecular Biology. John Wiley and Sons, New York, US.

Castro N, Toranzo AE, Nuñez S, Osorio CR and Magariños B. 2010. Evaluation of four polymerase chain reaction primer pairs for the detection of Edwardsiella tarda in turbot. Dis Aquat Org 90, 5561. http://dx.doi.org/10.3354/dao02203.

Chizhikov V, Rasooly A, Chumakov K and Levy DD. 2001. Microarray analysis of microbial virulence factors. Appl Environ Microbiol 67, 3258-3263. http://dx.doi.org/10.1128/AEM.67.7.3258-3263.2001.

Frans I, Michiels CW, Bossier P, Willems KA, Lievens B and Rediers H. 2011. Vibrio anguillarum as a fish pathogen: virulence factors, diagnosis and prevention. J Fish Dis 34, 643-661. http://dx.doi. org/10.1111/j.1365-2761.2011.01279.x.

González SF, Krug MJ, Nielsen ME, Santos Y and Call DR. 2004. Simultaneous detection of marine fish pathogens by using multiplex PCR and a DNA microarray. J Clin Microbiol 42, 1414-1419. http://dx.doi.org/10.1128/JCM.42.4.1414-1419.2004.

Hossain MT, Kim EY, Kim YR, Kim DG and Kong IS. 2012. Application of groEL gene for the species-specific detection of Vibrio parahaemolyticus by PCR. Lett Appl Microbiol 54, 67-72. http:// dx.doi.org/10.1111/j.1472-765X.2011.03174.x.

Hossain MT, Kim EY, Kim YR, Kim DG and Kong IS. 2013. Development of a groEL gene-based species-specific multiplex polymerase chain reaction assay for simultaneous detection of Vibrio cholerae, Vibrio parahaemolyticus and Vibrio vulnificus. J Appl Microbiol 114, 448-456. http:/dx.doi.org/10.1111/jam.12056.

Izumiya $\mathrm{H}$, Matsumoto $\mathrm{K}$, Yahiro $\mathrm{S}$, Lee J, Morita $\mathrm{M}$, Yamamoto $\mathrm{S}$, Arakawa E and Ohnishi M. 2011. Multiplex PCR assay for identification of three major pathogenic Vibrio spp., Vibrio cholera, Vibrio parahaemolyticus, and Vibrio vulnificus. Mol Cell Probes 25, 174-176. http://dx.doi.org/10.1016/j.mcp.2011.04.004.

Jeyasekaran G, Raj KT, Shakila RJ, Thangarani AJ and Sukumar D. 2011. Multiplex polymerase chain reaction-based assay for the specific detection of toxin-producing Vibrio cholerae in fish and fishery products. Appl Microbiol Biotechnol 90, 1111-1118. http:// dx.doi.org/10.1007/s00253-011-3175-9.

Junick J and Blaut M. 2012. Quantification of human fecal Bifidobacterium species by use of quantitative real-time PCR analysis targeting groEL gene. Appl Environ Microbiol 78, 2613-2622. http:// dx.doi.org/10.1128/AEM.07749-11.

Kim DG, Ahn SH, Kim LH, Park KJ, Hong YK and Kong IS. 2008. Application of the rpoS gene for species-specific detection of Vibrio vulnificus by real-time PCR. J Microbiol Biotechnol 18, 18411847.

Kim DG, Kim YR, Kim EY, Cho HM, Ahn SH and Kong IS. 2010. Isolation of the groESL cluster from Vibrio anguillarum and PCR detection targeting groEL gene. Fish Sci 76, 803-810. http://dx.doi. org/10.1007/s12562-010-0266-y.

Kim YR, Kim EY, Kim DG, Kim YO, Hossain MT and Kong IS. 2012. DNA array with the groESL intergenic sequence to detect Vibrio parahaemolyticus and Vibrio vulnificus. Anal Biochem 424, 32-34. http://dx.doi.org/10.1016/j.ab.2012.02.008.

Kita-Tsukamoto K, Oyaizu H, Nanba K and Simidu U. 1993. Phylogenetic relationships of marine bacteria, mainly members of the family Vibrionaceae, determined on the basis of 16S rRNA sequences. Int J Syst Bacteriol 43, 8-19. http://dx.doi.org/10.1099/0020771343-1-8.

Lan J, Zhang XH, Wang Y, Chen J and Han Y. 2008. Isolation of an unusual strain of Edwardsiella tarda from turbot and establish a PCR detection technique with the $g y r B$ gene. J Appl Microbiol 105, 644-651.

Nishibuchi M. 2006. The biology of vibrios. In: Molecular Identification. Thompson FL, Austin B and Swings J, eds. ASM Press, Washington, DC, US, pp. 44-64.

Paillard C, Le Roux F and Borrego JJ. 2004. Bacterial disease in marine bivalves, a review of recent studies: trends and evaluation. Aquat Living Resour 17, 477-498. http://dx.doi.org/10.1051/alr:2004054.

Park SI. 2009. Disease control in Korean aquaculture. Fish Pathol 44, 19-23. http://dx.doi.org/10.3147/jsfp.44.19.

Rao PSS, Lim TM and Leung KY. 2001. Opsonized virulent Edwardsiella tarda strains are able to adhere to and survive and replicate within fish phagocytes but fail to stimulate reactive oxygen intermediates. Infect Immun 69, 5689-5697. http://dx.doi.org/10.1128/ IAI.69.9.5689-5697.2001

Rodkhum C, Hirono I, Crosa JH and Aoki T. 2006. Multiplex PCR for simultaneous detection of five virulence hemolysin genes in Vibrio anguillarum. J Microbiol Methods 65, 612-618. http://dx.doi. org/10.1016/j.mimet.2005.09.009.

Toranzo AE, Magariños B and Romalde JL. 2005. A review of the main bacterial fish diseases in mariculture systems. Aquaculture 246, 37-61. http://dx.doi.org/10.1016/j. aquaculture.2005.01.002.

Yushan H, Lei L, Weijia L and Xiaoguang C. 2010. Sequence analysis of the groEL gene and its potential application in identification of pathogenic bacteria. Afr J Microbiol Res 4, 1733-1741. 